\title{
Konsumsi Vitamin D dan Zink dengan Kejadian Stunting pada Anak Sekolah SD Negeri 77 Padang Serai Kota Bengkulu
}

\author{
Mia Lestari Peri Putri ${ }^{1}$, Betty Yosephin Simanjuntak ${ }^{2}$, Tetes Wahyu W \\ ${ }^{1,2,3}$ Jurusan Gizi, Politeknik Kesehatan Kemenkes Bengkulu, Indonesia \\ Email: mialestariperiputri@gmail.com
}

\begin{abstract}
Consuming Vitamin D and Zinc with The Stunting of The Students of SD Negeri 77 Padang Serai Kota Bengkulu. Deficiency of micronutrition is one of the factors which influence the deficiency of chronic nutrition. Deficiency of vitamin D can lower the absorption of calcium and phosphor. Deficiency of zinc can stunt children because zinc has the main role on growth acceleration period both before and after their birth. One of the impacts of chronic nutrition deficiency is the descending of growth acceleration or linear disturbance so the children fail on gaining height potency which causes the children to become stunt. This research is purposed to know the relation of consuming vitamin D and zinc with the stunting of the students of SD Negeri 77 Padang Serai Kota Bengkulu. This research is kind of analytical observation research with a cross-sectional approach which is done from January to April in SD Negeri 77 Padang Serai Kota Bengkulu. There are 80 subjects in this research. The variable which is observed about consuming vitamin $\mathrm{D}$, consuming zinc and stunting the analysis used a chi-square test. In this research, the data is collected by using an interview with semi FFQ form (Food Frequency Questionnaire). The result of this research shows that there is a relation between consuming zinc and stunting to the students of SD Negeri 77 Padang Serai Kota Bengkulu, however, there is no relation between consuming vitamin D and stunting to the students of SD Negeri 77 Padang Serai Kota Bengkulu.
\end{abstract}

Keywords: Stunting, Vitamin D, Zinc

\begin{abstract}
Abstrak: Konsumsi Vitamin D dan Zink dengan Kejadian Stunting pada Anak Sekolah SD Negeri 77 Padang Serai Kota Bengkulu. Kekurangan gizi mikro merupakan salah satu faktor yang mempengaruhi kejadian kurang gizi kronis. Defisiensi vitamin D dapat menyebabkan penurunan efisiensi penyerapan kalsium dan fosfor. Kekurangan zink dapat menyebabkan stunting pada anak karena zink mempunyai peranan utama dalam periode percepatan pertumbuhan baik sebelum dan sesudah kelahiran. Salah satu dampak jika seorang anak kekurangan zat gizi kronis adalah terjadinya penurunan kecepatan pertumbuhan atau gangguan linear sehingga anak gagal dalam mencapai potensi TB yang mengakibatkan anak menjadi stunting (pendek). Penelitian ini bertujuan untuk mengetahui hubungan konsumsi vitamin D dan zink dengan kejadian stunting pada anak sekolah SD Negeri 77 Padang Serai Kota Bengkulu. Penelitian ini termasuk jenis penelitian observasional analitik dengan pendekatan cross sectional yang dilakukan pada bulan Januari sampai April di SD Negeri 77 Padang Serai Kota Bengkulu. Subjek dalam penelitian ini adalah siswa-siswi SD Negeri 77 Padang Serai Kota Bengkulu, yang berjumlah 80 siswa. Data yang dikumpulkan berupa konsumsi vitamin D, Konsumsi zink serta stunting yang dianalisis dengan uji chi square. Pengumpulan data dalam penelitian ini menggunakan teknik wawancara dengan menggunakan formulir semi FFQ (food frequency questionnaire). Hasil penelitian menunjukkan bahwa ada hubungan antara konsumsi zink dengan kejadian stunting pada anak sekolah SD Negeri 77 Padang Serai Kota Bengkulu namun tidak ada hubungan antara konsumsi vitamin D dengan kejadian stunting pada anak sekolah SD Negeri 77 Padang Serai Kota Bengkulu.
\end{abstract}

Kata Kunci: Stunting, Vitamin D, Zink

Anak sekolah dasar membutuhkan gizi yang baik untuk menunjang kegiatan belajar di sekolah. Gizi yang baik sangat mempengaruhi daya konsentrasi dan kecerdasaan anak dalam menerima dan menyerap setiap ilmu yang didapat di sekolah. Anak SD merupakan sasaran strategis dalam perbaikan gizi masyarakat. Hal ini menjadi penting karena anak SD sedang mengalami pertumbuhan secara fisik dan mental yang sangat diperlukan untuk menunjang kehidupannya di masa mendatang (Ningsih dkk, 2016).

Secara nasional prevalensi status gizi TB/U pada anak umur 5-12 tahun 30,7\% dimana $12,3 \%$ sangat pendek dan $18,4 \%$ pendek. Data provinsi Bengkulu prevalensi pendek anak umur 5-12 tahun lebih tinggi dari prevalensi nasional 
yaitu $32,1 \%$ dimana $15,1 \%$ sangat pendek dan $17,0 \%$ pendek. Data kota Bengkulu prevalensi pendek pada anak 5-12 tahun yaitu 28,8\% dimana $13,0 \%$ sangat pendek dan $15,8 \%$ pendek.

Kekurangan gizi mikro merupakan salah satu faktor yang mempengaruhi kejadian kurang gizi kronis (Taufiqurrahman dkk., 2009). Defisiensi vitamin D dapat menyebabkan penurunan efisiensi penyerapan kalsium dan fosfor (Valentina dkk, 2014). Vitamin D merupakan prohormon yang berperan penting dalam penyerapan kalsium di dalam usus (Pusparini, 2014). Vitamin D membantu penyerapan terhadap kalsium, karena apabila penyerapan kalsium terganggu maka pertumbuhan juga terganggu. Vitamin D juga membantu pengerasan tulang dengan cara mengatur agar kalsium tersedia dalam darah pada proses pengerasan tulang (Almatsier, 2001).

Kekurangan zink dapat menyebabkan stunting pada anak karena zink mempunyai peranan utama dalam sintesis protein, replikasi gen dan pembelahan sel yang sangat penting selama periode percepatan pertumbuhan baik sebelum dan sesudah kelahiran (Kusudaryati, 2014). Salah satu dampak jika seorang anak kekurangan zat gizi kronis adalah terjadinya penurunan kecepatan pertumbuhan atau gangguan linear sehingga anak gagal dalam mencapai potensi TB yang mengakibatkan anak menjadi stunting (pendek) (Siregar dkk., 2011). Tujuan studi ini adalah diketahui hubungan konsumsi vitamin D dan zink dengan kejadian stunting pada anak sekolah SD Negeri 77 Padang Serai Kota Bengkulu.

\section{METODE}

Penelitian ini merupakan penelitian observasional analitik dengan pendekatan penelitian cross sectional yang dilakukan pada bulan januari sampai april di SD Negeri 77 Padang Serai Kota Bengkulu. Subjek dalam penelitian ini adalah siswa-siswi SD Negeri 77 Padang Serai Kota Bengkulu. Jumlah subjek dalam penelitian ini sebanyak 80 subjek. Variabel yang diamati meliputi konsumsi vitamin $\mathrm{D}$ dan konsumsi zink serta status gizi TB/U. Dimana untuk variabel konsumsi vitamin $\mathrm{D}$ dan zink dikategorikan kurang jika konsumsinya $<80 \%$ dan baik jika konsumsinya $\geq 80 \%$, untuk variabel status gizi TB/U dikategorikan pendek jika status gizi $\mathrm{TB} / \mathrm{U}<-2 \mathrm{SD}$ dan dikategorikan normal jika status gizi $T B / U \geq-2$ SD. Pengumpulan data dalam penelitian ini menggunakan teknik wawancara dengan menggunakan formulir semi
FFQ (food frequency questionnaire). Data yang telah terkumpul dianalisis menggunakan uji chi square $2 \times 2$.

\section{HASIL}

Tabel 1. Distribusi Frekuensi Status Gizi, Konsumsi Vitamin D dan Zink Siswa

\begin{tabular}{lcc}
\hline \multicolumn{1}{c}{ Variabel } & n & \% \\
\hline Status Gizi & & \\
Normal & 61 & 76.2 \\
Pendek & 19 & 23.8 \\
Konsumsi Vitamin D & & \\
Kurang & 70 & 87.5 \\
Baik & 10 & 12.5 \\
Konsumsi Zink & & \\
Kurang & 64 & 76.2 \\
Baik & 16 & 23.8 \\
\hline
\end{tabular}

Pada tabel 1 diketahui bahwa responden yang mengalami stunting sebanyak 19 responden (23.8\%), serta responden yang kurang mengonsumsi vitamin D dan zink masing-masing $87.5 \%$ dan $76.2 \%$.

Tabel 2. Hubungan Konsumsi Vitamin D dengan Kejadian Stunting pada Anak Sekolah SD Negeri 77 Padang Serai Kota Bengkulu

\begin{tabular}{|c|c|c|c|c|c|c|c|}
\hline \multirow{3}{*}{$\begin{array}{l}\text { Konsumsi } \\
\text { Vitamin D }\end{array}$} & \multicolumn{4}{|c|}{ Status gizi TB/U } & \multirow{2}{*}{\multicolumn{2}{|c|}{ Total }} & \multirow{3}{*}{$\begin{array}{c}p \\
\text { value }\end{array}$} \\
\hline & \multicolumn{2}{|c|}{ Pendek } & \multicolumn{2}{|c|}{ Normal } & & & \\
\hline & $\mathbf{n}$ & $\%$ & $\mathbf{n}$ & $\%$ & $\mathbf{n}$ & $\%$ & \\
\hline Kurang & 17 & 24.3 & 53 & 75.7 & 70 & 100 & 1.000 \\
\hline Baik & 2 & 20 & 8 & 80 & 10 & 100 & \\
\hline Jumlah & 19 & 23.8 & 61 & 76.2 & 80 & 100 & \\
\hline
\end{tabular}

Berdasarkan tabel 2 diketahui bahwa terdapat 70 anak yang memiliki konsumsi vitamin D kurang yang terdiri dari $24.3 \%$ memiliki status gizi $\mathrm{TB} / \mathrm{U}$ pendek dan $75.7 \%$ memiliki status gizi TB/U normal. Sedangkan terdapat 10 anak yang memiliki konsumsi vitamin D baik terdiri dari $20 \%$ memiliki status $\mathrm{TB} / \mathrm{U}$ pendek dan $80 \%$ memiliki status gizi TB/U normal. Hasil uji statistik dengan uji chi square didapatkan nilai $p$-value $(>0.05)$.

Tabel 3. Hubungan Konsumsi Zink dengan Kejadian Stunting pada Anak SD Negeri 77 Padang Serai Kota Bengkulu

\begin{tabular}{|c|c|c|c|c|c|c|c|c|}
\hline \multirow{3}{*}{$\begin{array}{c}\text { Konsumsi } \\
\text { Zink }\end{array}$} & \multicolumn{4}{|c|}{ Status Gizi TB/U } & \multirow{2}{*}{\multicolumn{2}{|c|}{ Total }} & \multirow{3}{*}{$\begin{array}{c}p \\
\text { value }\end{array}$} & \multirow{3}{*}{$\begin{array}{c}\begin{array}{c}\text { Koefisien } \\
\text { phi }\end{array} \\
0.235\end{array}$} \\
\hline & \multicolumn{2}{|c|}{ Pendek } & \multicolumn{2}{|c|}{ Normal } & & & & \\
\hline & $\bar{n}$ & $\%$ & $\mathbf{n}$ & $\%$ & $\mathbf{n}$ & $\%$ & & \\
\hline Kurang & 12 & 18.8 & 52 & 81.2 & 64 & 100 & & \\
\hline Baik & 7 & 43.8 & 9 & 56.2 & 16 & 100 & & \\
\hline Jumlah & 19 & 23.8 & 61 & 76.2 & 80 & 100 & & \\
\hline
\end{tabular}

Berdasarkan tabel 3 diketahui bahwa terdapat 64 anak yang konsumsi zink kurang 
terdiri dari $18.8 \%$ yang status gizi $\mathrm{TB} / \mathrm{U}$ pendek dan $81.2 \%$ yang status gizi $\mathrm{TB} / \mathrm{U}$ normal. Kemudian terdapat 16 anak yang konsumsi zink baik terdiri dari $43.8 \%$ memiliki status gizi $\mathrm{TB} / \mathrm{U}$ pendek dan $56.2 \%$ yang status gizi TB/U normal. Berdasarkan hasil uji statistik dengan uji chi square didapatkan nilai $p$-value $(<0.05)$ serta didapatkan hasil nilai koefisien phi 0.235 yang menunjukkan ada hubungan antara konsumsi zink dengan kejadian stunting.

\section{PEMBAHASAN}

\section{Hubungan Konsumsi Vitamin D dengan Stunting}

Hubungan konsumsi vitamin D dengan kejadian stunting dianalisis dengan menggunakan uji chi square hasil yang didapatkan yaitu $p$-value 1.000 dengan demikian dapat disimpulkan bahwa konsumsi vitamin D bukan merupakan faktor risiko terhadap kejadian stunting. Berdasarkan hasil penelitian bahwa sebagain besar responden konsumsi vitamin D kurang namun memiliki status gizi normal.

Hasil penelitian menunjukkan konsumsi vitamin D yang kurang namun banyak sampel yang status gizinya normal, hal ini karena sumber vitamin D tidak hanya berasal dari makanan sumber vitamin D namun juga dapat dibentuk di kulit dengan bantuan sinar matahari. Anak-anak SD Negeri 77 Padang Serai Kota Bengkulu hampir merata tinggal di pesisir pantai dan anakanak juga kebanyakan beraktifitas di luar rumah sehingga paparan sinar matahari sangat mudah diperoleh oleh anak-anak SD Negeri 77 Padang Serai Kota Bengkulu. Oleh karena dalam penelitian ini hanya membahas tentang sumber vitamin D dari makanan saja, ada kemungkinan vitamin D anak-anak SD Negeri 77 Padang Serai Kota Bengkulu diperoleh dari sumber matahari/ pembuatan di kulit.

Anak-anak SD Negeri 77 Padang Serai Kota Bengkulu kebanyakan tinggal di tepi pantai, memungkinkan konsumsi ikan mereka cukup, namun jenis ikan yang tinggi kandungan vitamin D antara lain ikan salmon, makarel dan tuna tidak mudah diperoleh oleh siswa-siswi SD Negeri 77 Padang Serai Kota Bengkulu, sehingga kurang mencukupi kebutuhan vitamin D berdasarkan AKG. Anjuran vitamin D berdasarkan AKG yaitu untuk anak laki-laki dan perempuan usia 9-12 tahun sebesar $15 \mu \mathrm{g}$. Selain itu siswa-siswi lebih sering mengonsumsi ikan asin dan ikan nila/mujair.
Kurangnya konsumsi vitamin D maka proses penyerapan kalsium dan fosfor juga terganggu, yang akan berdampak pada proses pertumbuhan terganggu, hal inilah yang dapat menyebabkan terjadinya kependekan/stunting. Kurangnya konsumsi vitamin D dikarenakan anak-anak kurang mengonsumsi makanan sumber vitamin D. Kurangnya konsumsi vitamin D dari makanan yang dialami anak-anak SD Negeri 77 Padang Serai Kota Bengkulu. Defisiensi vitamin D tersebut masih dapat dicegah dengan paparan sinar matahari yang lebih karena wilayah tempat tinggal yang berada di tepi pantai, meskipun dalam penelitian ini tidak membahas tentang paparan sinar matahari, namun hal tersebut dapat menghambat kekurangan vitamin $\mathrm{D}$ untuk proses pertumbuhan tinggi badan anak-anak SD Negeri 77 Padang Serai Kota Bengkulu.

Penelitian ini sejalan dengan penelitian yang dilakukan oleh Valentina, dkk, (2014) yang menunjukkan bahwa asupan vitamin D tidak berpengaruh secara signifikan terhadap status gizi. Menurut Pusparini (2014) ada dua sumber vitamin D yaitu lewat pembuatan dikulit dan dampak asupan makanan. Sumber vitamin D banyak terdapat pada minyak ikan, telur, hati, berbagai jenis ikan seperti ikan makarel, ikan salmon, ikan sarden dan ikan tuna (Yosephin, 2016).

Pusparini (2014) juga menyatakan bahwa faktor defisiensi vitamin D lainnya juga disebabkan oleh warna kulit yang gelap karena semakin gelap kulit seseorang maka semakin lama juga waktu yang dibutuhkan untuk membentuk vitamin $\mathrm{D}$, penggunaan tabir surya, cara berpakaian yang tertutup dan berlindung di tempat teduh.

Devi (2012) menyatakan bahwa vitamin D pada anak sekolah sangat penting karena erat sekali fungsinya untuk kesehatan tulang yang berperan dalam meningkatkan penyerapan kalsium dan fosfor dalam usus halus, meningkatkan mobilisasi kalsium, meningkatkan fosfor tulang, meningkatkan mineralisasi tulang, dan menjaga konsentrasi kalsium dalam darah. Dengan tercukupinya vitamin D, maka pertumbuhan tulang anak khususnya pertambahan tinggi badan anak akan lebih optimal.

\section{Hubungan Konsumsi Zink dengan Stunting}

Hubungan konsumsi zink dengan kejadian stunting dianalisis dengan menggunakan uji chi square didapatkan nilai $p$-value $(\geq 0.05)$ dengan demikian dapat disimpulkan bahwa konsumsi 
zink merupakan faktor risiko terhadap kejadian stunting. Berdasarkan penelitian sebagian besar anak-anak SD Negeri 77 Padang Serai Kota Bengkulu, konsumsi zink mereka kurang dan sebagian $24.3 \%$ memiliki status gizi pendek.

Kebanyakan anak-anak sudah banyak yang mengonsumsi makanan sumber zink namun jumlah yang dikonsumsi masih kurang bila dibandingkan dengan AKG dimana jumlah konsumsi zink yang dianjurkan AKG untuk anak usia 7-9 tahun $11 \mathrm{mg}$, untuk laki-laki usia 10-12 tahun $14 \mathrm{mg}$ dan untuk anak perempuan usia 1012 tahun sebesar $13 \mathrm{mg}$. Rata-rata anak-anak mengonsumsi zink hanya $50 \%$ dari jumlah yang dianjurkan. Sehingga konsumsi zink anak-anak SD Negeri 77 Padang Serai Kota Bengkulu masih sangat kurang.

Sumber zink berasal dari protein hewani seperti daging, hati, kerang, telur serta makanan laut namun berdasarkan hasil wawancara dengan semi FFQ yang dikonsumsi oleh anak-anak SD Negeri 77 Padang Serai Kota Bengkulu hanya berasal dari daging dan telur serta frekuensi konsumsi daging dan telur tidak setiap hari bahkan dapat dikategorikan jarang. Untuk mengonsumsi makanan laut pun anak-anak SD Negeri 77 Padang Serai Kota Bengkulu masih jarang dan kebanyakan mengonsumsi ikan yang sudah diawetkan seperti ikan asin serta ikan air tawar seperti ikan mas dan ikan nila/mujair.

Fungsi utama zink sebagai sintesis protein sehingga anak-anak SD Negeri 77 Padang Serai Kota Bengkulu yang mengalami kekurangan zink akan menghambat pertumbuhan tinggi badan mereka, gangguan perkembangan kecerdasan, terhambat pematangan seksual, akan mudah terkena infeksi, mengalami kehilangan nafsu makan dan menyebabkan pertumbuhan tinggi badan mereka terganggu.

Sumber zink menurut Kusudaryati (2014) terdapat pada protein hewani, seperti daging, hati, kerang, dan telur. Serelia tumbuk dan kacangkacangan.Yuniastuti (2008) menyebutkan sumber zink banyak terdapat pada tiram, makanan laut, ragi, unggas dan ikan. Devi N (2012) menyebutkan sumber zink banyak terdapat pada tiram, kepiting, produk susu, jamur dan bayam.

Penelitian ini sejalan dengan penelitian yang dilakukan oleh Anindita (2012) yang menunjukkan bahwa ada hubungan antara tingkat kecukupan zink dengan stunting/pendek dilihat dari indikator TB/U. Menurut Anindita (2012) zink sangat erat kaitannya dengan metabolisme tulang, sehingga zink berperan secara positif pada pertumbuhan dan perkembangan dan sangat penting pada tahap-tahap pertumbuhan dan perkembangan.
Penelitian ini juga sejalan dengan penelitian yang dilakukan oleh Dewi (2016) zat gizi mikro yang memiliki pengaruh bermakna zink dengan kejadian stunting. Pada anak balita yang mengalami stunting lebih banyak yang kekurangan konsumsi zink dibanding dengan anak balita yang normal. Hasil penelitian ini sejalan dengan yang dilakukan oleh Abunada (2013) di negara Palestina bahwa ada hubungan antara zink dengan stunting. Remaja yang mengalami defisiensi zink berisiko terkena stunting dibanding remaja yang memiliki asupan zink normal.

Almatsier (2001) menyatakan bahwa zink berfungsi dalam metabolisme tulang, transport oksigen, dan pemusnahan radikal bebas, pembentukan struktur dan fungsi membran serta proses penggumpalan darah. Karena zink berperan dalam reaksi-reaksi yang luas, kekurangan zink akan berpengaruh terhadap jaringan tubuh terutama pada saat pertumbuhan. Devi (2012) menyatakan bahwa bila anak SD mengalami kekurangan zink, maka dapat menyebabkan pertumbuhan tinggi badan terhambat (pendek), gangguan perkembangan kecerdasan anak (gangguan fungsi otak), terhambatnya pematangan seksual, mudah terkena infeksi, dan kehilangan nafsu makan.

Kusudaryati (2014) menyatakan bahwa kekurangan zink dapat menyebabkan terjadinya stunting pada anak karena zink mempuyai peran utama dalam sintetis protein, replikasi gen dan pembelahan sel yang sangat penting selama periode percepatan pertumbuhan baik sebelum maupun sesudah kelahiran. Dampak utama jika terjadi kekurangan zink adalah kegagalan pertumbuhan bukan hanya efek replikasi sel dan metabolisme asam nukleat tetapi juga sebagai mediator hormon pertumbuhan yaitu Insulin-like Growth Factor I (IGF I).

Agustian (2009) menyatakan bahwa zink juga berperan dalam sintetis protein yang dibutuhkan untuk membentuk jaringan baru, pertumbuhan dan perkembangan tulang yang normal apabila mengkonsumsi makanan sumber zink kurang maka akan menghambat sintetis protein dan dengan terhambatnya sintetis protein maka akan terhambat pula proses pertumbuhan dan perkembangan tulang yang akan berdampak pada terjadinya kependekan/stunting.

\section{SIMPULAN}

Hasil penelitian menunjukkan bahwa ada hubungan antara konsumsi zink dengan kejadian stunting pada anak sekolah SD Negeri 77 Padang 
Serai Kota Bengkulu ditunjukkan dengan nilai $p$ value ( $\geq 0.05)$,serta tidak ada hubungan antara konsumsi vitamin D dengan kejadian stunting pada anak sekolah SD Negeri 77 Padang Serai Kota Bengkulu ( $p$-value $>0.05$ ).

\section{SARAN}

Siswa-siswi perlu untuk meningkatkan konsumsi bahan makanan sumber vitamin $\mathrm{D}$ dan zink seperti lauk hewani dan beberapa jenis ikan laut. Perlu peningkatan aktivitas di luar kelas sebelum jam sembilan (9) pagi agar siswa-siswi dapat terpapar dengan sinar matahari pagi untuk memperoleh provitamin D.

\section{DAFTAR PUSTAKA}

Abunada,S., Jalambo, O., Ramadan, \& Zabut. 2013. Nutritional assessment of zinc among adolescents in the Gaza StripPalestine. Open Journal of Epidemiology, pp.105-10

Almatsier, S. 2001. Prinsip Dasar Ilmu Gizi. Jakarta: PT Gramedia Pustaka Utama.

Agustian L, Tiansa Sembiring, \& Ani Ariani. 2009. Peran Zinkum Terhadap Pertumbuhan Anak. Sari Pediatri, Volume XI, Nomor 4, Desember 2009;244-249.

Anindita, P. 2012. Hubungan Tingkat Pendidikan Ibu, Pendapatan Keluarga, Kecukupan Protein \& zinc dengan Stunting (Pendek) pada Balita usia 6-36 Bulan di Kecamatan Tembalang Kota Semarang. Jurnal Kesehatan Masyarakat 1(2): 617-626.

Devi, N. 2012. Gizi Anak Sekolah. Jakarta: Kompas.

Dewi. I. A. K. C. dan Kadek Tresna Adhi, 2016. Pengaruh Konsumsi Protein dan Seng Serta Riwayat Penyakit Infeksi Terhadap Kejadian Stunting Pada Anak Balita Umur 24-59 Bulan di Wilayah Kerja Puskesmas Nusa Penida Iii. Arc. Com. Health, Vol. 3 No. $1: 36$ - 46

Kusudaryati, D. P. D. 2014. Kekurangan Asupan Besi dan Seng Sebagai Faktor Penyebab Stunting pada Anak. Journal Profesi 10:58-59.

Ningsih, Y. A., Suyanto dan Tuti Restuastuti. 2016. Gambaran Status Gizi Pada Siswa. JOM FK 3(2) :1-12.
Pusparini. 2014. Defisiensi vitamin D terhadap penyakit. Indonesia Journal of Clinical Pathology and Medical Laboratory 21(1):90-95.

Siregar, R., Lilisinawati, Endang Dewi Lestari, dan Harsono Salimo. 2011. Effect of zinc supplementation on morbidity among stunted children in Indonesia. Paediatrica Indonesiana, 51(3) 128-132.

Taufiqurrahman, Haman Hadi, Madarina Julia, dan Susilowati Herman. 2009. Defisiensi Vitamin A dan Zinc sebagai Faktor Risiko Teerjadinya Stunting pada Balita di Nusa Tenggara Barat. Media Penelitian dan Pengembangan Kesehatan, 19(2):84-94.

Valentina, V., Nurheni Sri Palupi, dan Nuri Andarwulan, 2014. Asupan Kalsium dan Vitamin D Pada Anak Indonesia Usia 2-12 Tahun. Jurnal Teknologi dan Industri Pangan 25(1): 83-89.

Yosephin, B., Faisal Anwar, Hadi Riyadi, Ali Khomsan, dan Nur Elly. 2016. Food Sources of Vitamin D and its Deficiency in Worker Women. 4th Asian Academic Society International Conference (AASIC). Globalizing Asia: Integrating Science, Technology and Humanities for Future Growth and Development: 233-239.

Yuniastuti, A. 2008. Gizi dan Kesehatan. Yogyakarta: Graha Ilmu. 